Roux's Arch Dev Biol (1993) 202:371-381

\title{
A late role for a subset of neurogenic genes to limit sensory precursor recruitments in Drosophila embryos
}

\author{
Rolf Bodmer ${ }^{1}$, Lily Yeh Jan ${ }^{2}$, Yuh-Nung Jan ${ }^{2}$ \\ ${ }^{1}$ Department of Biology, University of Michigan, Ann Arbor, MI 48109-1048, USA \\ ${ }^{2}$ Howard Hughes Medical Institute, Departments of Physiology and Biochemistry, University of California in San Francisco, San Francisco, \\ CA 94143-0724, USA
}

Received: January 15/Accepted in revised form: March 1st, 1993

Summary. In Drosophila, mutations in a class of genes, the neurogenic genes, produce an excess of neurons. This neural hyperplasia has been attributed to the formation of more than the normal number of neuronal precursor cells at the expense of epidermal cells. In order to find out whether the neurogenic genes only act at this intial step of neurogenesis, we studied the replication pattern of the sensory organ precursor cells by monitoring BrdU incorporation in embryos mutant for Notch $(N)$, Delta $(D l)$, mastermind (mam), almondex (amx), neuralized (neu), big brain $(b i b)$ and the Enhancer of split-Complex $(E(s p l)-C)$. Using temperature sensitive alleles of two of the neurogenic genes, $D I$ and $N$, we also induced an acute increase of replicating sensory precursors by shifting briefly to the restricted temperature. We have found that the loss of function of all the seven neurogenic loci that were tested causes an increase in replicating sensory precursor cells, consistent with the model that these neurogenic genes normally participate in the process of restricting the number of neuronal precursors. Whereas the temporal pattern of replication appeared normal in mutants of five of the seven neurogenic loci, in $N$ and mam embryos replicating PNS cells are present beyond the time when they normally undergo replication. Experiments with colchicine suggest that many of these late replicating cells may be newly emerging precursors and probably not additional cell divisions of already recruited precursors. Thus, different neurogenic genes may be required over different periods of time for the specification of sensory precursor cells.

Key words: Neurogenesis - Drosophila - Neurogenic genes - PNS - Lineage

\section{Introduction}

Early during embryogenesis, a subset of ectodermal cells in the Drosophila embryo become neuronal precursors

Correspondence to: $\mathrm{R}$. Bodmer and undergo stereotyped patterns of cell divisions to produce neurons. The specification of neuronal precursors may involve the function of two groups of genes, the proneural genes and the neurogenic genes (reviewed in Ghysen and Dambly-Chaudiere 1989; Jan and Jan 1990; Campos-Ortega and Jan 1991; Artavanis-Tsakonas and Simpson 1991). The proneural genes, such as the genes of the achaete-scute complex and daughterless, are required to render groups of ectodermal cells competent for formation of neuronal precursor cells. Some of the proneural genes show restricted expression in proneural clusters (Romani et al. 1987, 1989; Cabrera et al. 1987; Martin-Bermudo et al. 1991; Cubas et al. 1991; Skeath and Carroll 1991, 1992). If the function of one of the proneural genes is lost all or a specific subset of neurons are absent (Dambly-Chaudiere and Ghysen 1987; Dambly-Chaudiere et al. 1988; Caudy et al. 1988; Brand and Campos-Ortega 1988; Jimenez and CamposOrtega 1990).

Subsequent to the formation of the proneural clusters, the neurogenic genes are thought to be involved in limiting the number of neuronal precursor cells recruited from the proneural clusters. Embryos mutant for the neurogenic genes $N, D l$, mam, amx, neu, bib and $E(s p l)-C$ all exhibit a similar hyperplasia of neurons in the central nervous system presumably due to an excess number of neuroblasts (Lehmann et al. 1981, 1983; Campos-Ortega 1988; Cabrera 1990; Artavanis-Tsakonas and Simpson 1991; Campos-Ortega and Jan 1991).

Hyperplasia of sensory organs is also observed in the peripheral nervous system of neurogenic mutants (Hartenstein and Campos-Ortega 1986). The early pattern of neuronal precursors in these mutants is similar to that in the wild-type (Goriely et al. 1991). Shortly after these first precursors appear near the center of the proneural clusters of the neurogenic mutant embryos many more cells, perhaps all cells of the proneural clusters, become neuronal precursors (see also Brand and Campos-Ortega 1988; Cabrera 1990; Heitzler and Simpson 1991; Goriely et al. 1991; de Celis et al. 1991; MartinBermudo et al. 1991; Skeath and Carroll 1992). It is, 
however, not known if the supernumerary precursor cells in neurogenic mutants go through cell divisions. Nor is it known if the neuronal precursors in neurogenic mutants undergo additional cell divisions as compared to those of the wild-type embryo, or if additional neuronal precursor cells emerge in these mutants later during development. Finally, it has not been established whether all neurogenic genes function in a similar way in preventing neural hyperplasia during embryogenesis or whether they are required only for the initial specification of neuronal precursors.

The neurogenic genes may function at multiple levels of neurogenesis. During postembryonic development, $N$ first functions in the choice of an ectodermal cell between an epidermal and a neural fate, probably in a cell autonomous fashion (Heitzler and Simpson 1991; de Celis et al. 1991), and later $N$ is also required for the progeny of the neuronal precursors to choose between the cell fate of a neuron and the cell fate of a support cell (Hartenstein and Posakony 1990). Multiple requirements for $N$ have also been found in the development of the visual system (Cagan and Ready 1990). It is not known if some of the other neurogenic genes also have multiple functions. In the case of $b i b$, it is likely that during neurogenesis this gene is only required for the initial specification of neuronal precursors (Rao et al. 1992).

In wild-type embryos, transplantation of ectodermal cells from older to younger embryos showed that epidermal cells removed from embryos at stages after neuroblast segregation can switch to a neural fate in younger hosts (Technau et al. 1988). These studies suggests that the competence of ectodermal cells to adopt either epidermal or neural fate can be retained or regained for a rather long period of time. It is not known whether any of the neurogenic genes normally function to limit the recruitment of neuronal precursors later in embryogenesis.

In order to compare the effects of different neurogenic mutations on the number and the time of appearance of neural precursors, we examined the pattern of Bromodeoxyuridine (BrdU) incorporation into neuronal precursors of the peripheral nervous system (PNS) of Drosophila embryos. Most sensory precursor cells emerge after the peripheral ectoderm has completed its final wave of mitosis, so that the only replicating cells in these regions are due to the sensory precursor lineages (Bodmer et al. 1989). Moreover, both the sensory organs and their precursors appear in a stereotyped fashion, thereby allowing ready identification of individual sensory organs and their precursors (Bodmer et al. 1989).

For a better appreciation of the neurogenic gene functions, we studied the phenotypes of an allelic series encompassing a range of severity of mutations. We also examined the effects of removing the maternal contribution of one of the neurogenic genes which is known to have its product supplied maternally. In addition to analyzing the temporal sequence of BrdU incorporation into neuronal precursors, we used colchicine treatment to reveal the appearance of new precursor cells, and different regimes of temperature shift experiments of temperature-sensitive mutants to examine the temporal requirement of different neurogenic genes. Our studies reveal qualitative differences between different neurogenic genes as to when their functions are required to prevent additional embryonic epidermal cells from adopting the fate of neuronal precursors.

\section{Materials and methods}

Fly stocks. The following fly stock have been used in this study: Oregon $\mathrm{R}$ as the wild-type stock and the neurogenic mutants: $N^{5 \operatorname{se11}}, \operatorname{Df}(1) N^{8}, a m x^{1}$ (Lindsley and Gress 1968); $N^{t s 1}$ (Shellenbarger and Mohler 1978); mam $^{23}$, mam $^{223}$, neu ${ }^{K X 9}, D l^{9 P 39}, D l^{6 B 37}$ (Lehmann et al. 1981, 1983; Lindsley and Zimm 1985, 1990), $b_{i b} b^{I I 9-5}$ (Rao et al. 1990), Df(3R)E(spl) ${ }^{R-A 7.1}$ (deletion of the distal portion f the $E$ (spl)-C, Knust et al. 1987; Ziemer et al. 1988), $\mathrm{Df}(3 \mathrm{R}) E(s p I)^{8 D O 6}$ (deletion of the complete $E(s p I)-C$ including the neurogenic gene groucho; Lehmann et al. 1981, 1983; Juergens et al. 1984; Ziemer et al. 1988; Schrons et al. 1992). The mutant stocks were kept over appropriate balancer chromosomes at $25^{\circ} \mathrm{C}$, except for $N^{t s 1}$ which was kept homozygous at $18^{\circ} \mathrm{C}$. For some experiments $N^{55 e 11} / \mathrm{FM} 7$ females were crossed to $N^{t s 1} / Y$ males and the transheterozygous embryos were analyzed.

Germline clones. In order to produce embryos that were maternally as well as zygotically mutant for Notch, $N^{5 e^{11}} / \mathrm{FM} 7$ females were crossed to ovo ${ }^{D 1} / Y$ males. Mitotic recombinants were generated by irradiating the progeny about $40-50 \mathrm{~h}$ after egg laying with 1000 r X-rays. Emerging N/ovo ${ }^{D 1}$ females were crossed to wild-type males en masse. Since only those germline clones that are genotypically homozygous for $N$ produce eggs, half of the embryos are maternally as well as zygotically mutant for Notch, and the other half is only lacking the maternal componant. Cuticle preparations of a sample collection revealed the expected reduction in cuticle formation of about half of the embryos (Jimenez and CamposOrtega 1982) which were therefore of the genotype $N^{5 \operatorname{se1} 1} / \mathrm{Y}$.

Labelling with Bromodeoxyuridine ( $B r d U$ ). Embryos were collected for one hour at $18^{\circ} \mathrm{C}$ and aged in a moist chamber at $25^{\circ} \mathrm{C}$ until they reached the appropriate age unless otherwise indicated. Incorporation of the thymidine-analog BrdU (Sigma) into replicating cells and subsequent immunohistochemical detection was performed as described in Bodmer et al. (1989). Briefly, dechorionated embryos were permeabilized with octane for $4 \mathrm{~min}$, transferred to a wide tube containing $1 \mathrm{mg} / \mathrm{ml} \mathrm{BrdU}$ in insect medium and the octane evaporated from the surface. After incubation at $25^{\circ} \mathrm{C}$ for 30 min the embryos were fixed, devitellinized, treated for one hour with $2 \mathrm{~N} \mathrm{HCl}$ and immunohistochemically stained with anti-BrdU antibodies (1:50, Becton-Dickinson).

Colchicine treatment. The microtubule depolymerizing activity of colchicine arrests dividing cells in metaphase. Incubation of embryos with colchicine prior to BrdU labelling will prevent further replication of the cells locked in metaphase and consequently block incorporation of BrdU. Those cells that were not dividing during colchicine treatment will still incorporate BrdU, if they now initiate replication during the labelling period. This regime was used to determine if newly emerging PNS precursor cells are responsible for late replicating cells in the periphery of $N$ and mam mutant embryos or if this phenotype was due to extended lineages (Figs. 3 and 4). Thus, $N^{55 e 11}$ and mam $^{23}$ embryos, and as controls wildtype and $D l^{6337}$ (at $25^{\circ} \mathrm{C}$ ) embryos, were permeabilized with octane (see above) at 6 or $7 \mathrm{~h}$ of development. Then, embryos were incubated for $1 \mathrm{~h}$ in insect medium containing $0.2 \mathrm{mg} / \mathrm{ml}$ colchicine (same results were obtained with 0.1 or $0.5 \mathrm{mg} / \mathrm{ml}$ colchicine). After several rinses BrdU containing medium was added and embryos were incubated for $30 \mathrm{~min}$. The subsequent immunohistochemical staining was carried out as described above. 
Temperature-shift experiments with $N^{t s 1}$ and $D l^{6037}$. For temperature-shift experiments, homozygous $N^{t s 1}$ embryos and embryos derived from the $D l^{6 B 37} / \mathrm{TM} 3$ stock were collected at $18^{\circ} \mathrm{C}$ for $1 \mathrm{~h}$ and incubated in a moist chamber at the same temperature until they reached a developmental stage corresponding approx. 4-5, 5-6 and $6-7 \mathrm{~h}$ of development at $25^{\circ} \mathrm{C}$ (stage 9, 10 and early stage 11, respectively, Campos-Ortega and Hartenstein 1985). At that point, the temperature was shifted to 30 or $32^{\circ} \mathrm{C}$ for $1 \mathrm{~h}$. (It was estimated that the embryos developed about twice as fast as at $25^{\circ} \mathrm{C}$ ). Then, the embryos were quickly prepared for BrdU incorporation $\left(15-20 \mathrm{~min}\right.$ at $30-32^{\circ} \mathrm{C}$ ). The quarter of embryos expected to be homozygous for $D l^{6 B 37}$ could easily be recognized by the moderate but clearly visible hyperplasia of replicating cells in the CNS. Embryos kept at $18^{\circ} \mathrm{C}$ and wild-type, temperatureshifted embryos served as controls and were indistinguishable from wild-type embryos kept at $25^{\circ} \mathrm{C}$. For some experiments embryos from the cross, $N^{5 e^{11}} / \mathrm{FM} 7 \times N^{t s 1} / \mathrm{Y}$, were subjected to the same regime. The phenotype observed in $N^{55 e 11} / N^{t s 1}$ embryos was only slightly stronger than for homozygous $N^{t s 1}$ embryos. In another experiment, cuticle preparations of $N^{5511}$ embryos derived from germline clones (Jimenez and Campos-Ortega 1982) were compared with cuticle preparations from $N^{\text {ts } 1}$ embryos which developed at $30-32^{\circ}$ and whose parents had been kept at $30-32^{\circ} \mathrm{C}$ for one or two days prior to embryo collection. The observed phenotypes were comparable; the dorsal cuticle was reduced to a small patch hardly more than spiracles and filzkorper (data not shown).

Antibody staining. In order to investigate whether the extra replicating cells induced by temperature-shifts of $N^{t s 1}$ and $D I^{6 B 37}$ embryos would give rise to sensory organ cells, a similar temperature-shift protocol was used as for BrdU labelling (see above), but the embryos were stained with an antiserum against $\mathrm{Cut}$, a nuclear protein expressed specifically by a subset of sensory organ cells and their precursors (Blochlinger et al. 1990). Embryos were shifted from $18^{\circ} \mathrm{C}$ to the non-permissive temperature of $30-32^{\circ} \mathrm{C}$ for $11 / 4 \mathrm{~h}$ before fixation which is the same length of temperature-shift used for BrdU labelling. After fixation, these embryos were stained with anti-Cut antibodies described previously (Bodmer and Jan 1987). The crude anti-Cut serum had been preabsorbed with an equal volume of fixed $0-4 \mathrm{~h}$ old wild-type embryos in order to eliminate non-specific background staining and was used at a dilution of $1: 2000$.

\section{Results}

The pattern of replication of sensory organ precursor cells was investigated with BrdU in strong and intermediate strength mutant alleles of seven of the known neurogenic loci in Drosophila embryos (see Materials and Methods). The phenotype of these mutations was observed between $61 / 2$ and $11 \mathrm{~h}$ of development (at $25^{\circ} \mathrm{C}$, stages 11-14, Campos-Ortega and Hartenstein 1985), which is after the last mitotic wave of the peripheral ectoderm (Bodmer et al. 1989). In wild-type embryos the sensory precursor replication pattern is very stereotyped: precursors start and terminate their divisions between $51 / 2$ and $81 / 2 \mathrm{~h}$ of development. Most of PNS precursors normally become recruited between $51 / 2$ and 6 $1 / 2 \mathrm{~h}$ of development (Goriely et al. 1991) and BrdU incorporation into these cells is completed between 7 $1 / 2$ and $81 / 2 \mathrm{~h}$ (Bodmer et al. 1989). Since each sensory organ appears to derive from a single precursor and two to three cell divisions are needed to generate all the cells of a sensory organ, the average cell cycle length would have to last about one hour (see also Bodmer et al. 1989), similar to what has been observed for em- bryonic cells after cycle 14 (Foe et al. 1989). Therefore, a 30 min incubation with BrdU was chosen, which is expected to label almost exclusively precursors in Sphase before they complete mitosis.

\section{Replication pattern of the supernumerary sensory precursors in neurogenic mutant embryos}

The mutant phenotype at $61 / 2 \mathrm{~h}$ of development is similar for all the neurogenic genes and varies primarily with the strength of the allele: All seven genes when mutated cause a hyperplasia of replicating sensory precursors (Fig. 1, left panels. The dorsal and lateral PNS cluster of an abdominal segment are indicated in each panel by brackets). Compared with the wild-type (Fig. 1A), the number of BrdU labeled cells in the periphery of mutant embryos is increased by a factor of 1.5 to 4 (Fig. 1, left panels). These results are consistent with the view that soon after the first sensory precursors emerge many more precursors are recruited in neurogenic mutant embryos (see Goriely et al. 1991). The observed hyperplasia of replicating cells in the PNS region suggests that extra precursors start dividing as do the normal PNS precursors.

In wild-type, BrdU incorporation in the PNS decreases progressively with time (Fig. $1 \mathrm{~A}-\mathrm{C}$, between 6 $1 / 2$ and $81 / 2 \mathrm{~h}$ of development) as more and more precursors have completed their cell divisions (Bodmer et al. 1989). When the BrdU incorporation is monitored in neurogenic mutants (Fig. 1D-U) the number of replicating cells in the periphery also decreases with time (Fig. 1, left panels: $61 / 2 \mathrm{~h}$ of development, middle panels: 7 $1 / 2 \mathrm{~h}$ of development, right panels: $81 / 2 \mathrm{~h}$ of development). This is consistent with the idea that in neurogenic mutants the extra precursors also undergo a limited number of cell divisions. The $N$ and mam mutant embryos show a much more graded decline of the number of BrdU labelled cells (Fig. 1 D-I), whereas the temporal patterns observed in $\mathrm{Dl}, a m x, n e u, b i b$ and $E(s p l)-C$ mutant embryos are similar to that observed in wild-type embryos. There are virtually no replicating cells oserved in the periphery at $81 / 2 \mathrm{~h}$ in wild-type and mutants of the latter five neurogenic genes, irrespective of the strength of the particular mutant allele (Fig. $1 \mathrm{~J}-\mathrm{U}$, data for $b i b$ and $E(s p l)-C$ are not shown). In contrast to the divisions in the PNS, CNS neuroblasts divide many more times and continue taking up BrdU for at least several more hours in mutant as well as wild-type embryos (data not shown). The simplest interpretation for the observed mutant phenotype of these five loci is that the observed neural hyperplasia is due to an increased number of ectodermal cells being recruited as sensory precursor cells rather than an increased number of cell divisions of the precursors, though it can not be ruled out that the cell cycle lengths and the number of cell divisions are altered in such a fashion in mutants of these five neurogenic loci that termination of replication happens at the same time as in wild-type embryos. In the case of $b i b$, the relative increase in replicating cells in the PNS has been found to correlate with the increase in differentiating sensory organs (Rao et al. 1992), con- 

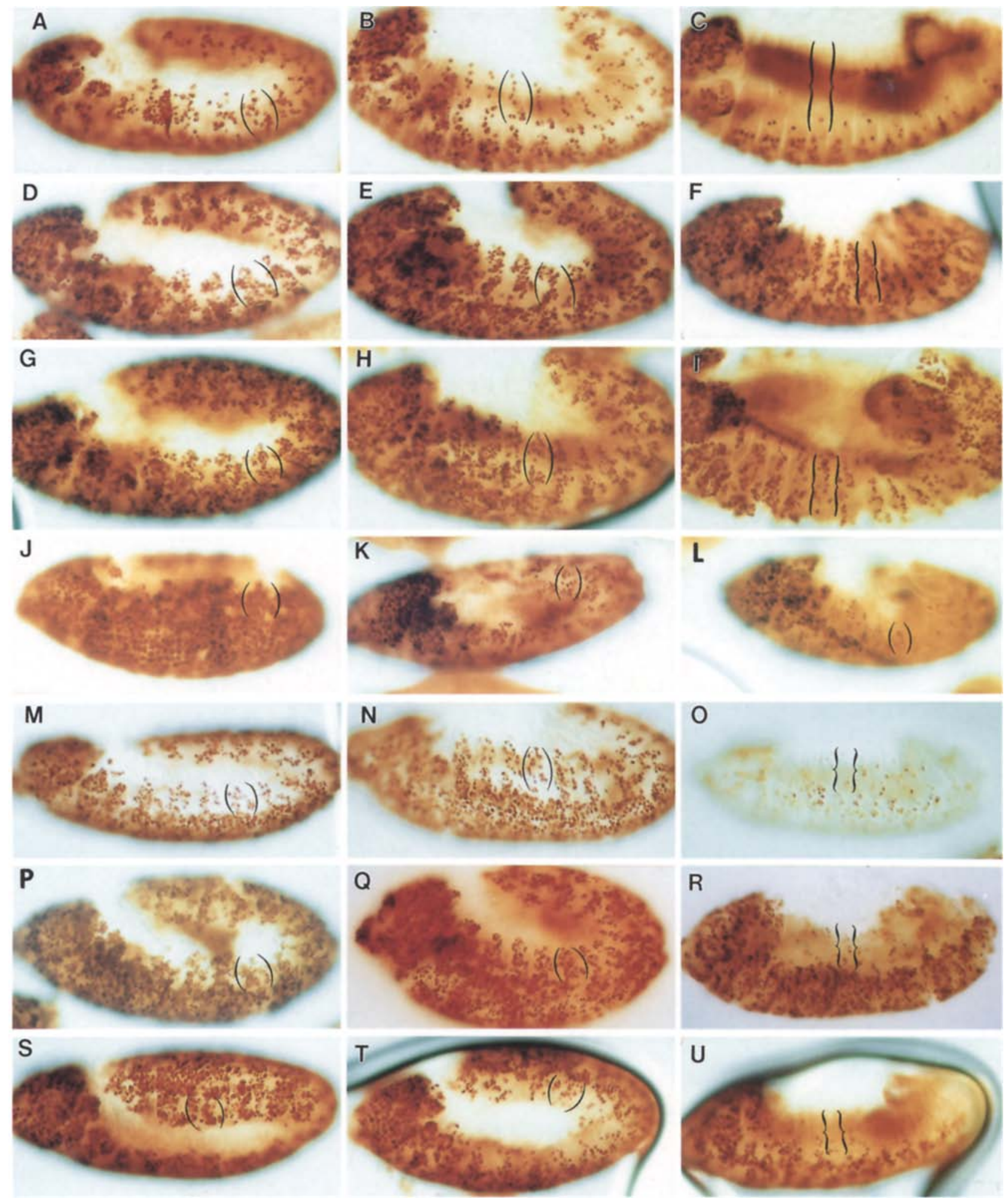

Fig. 1 A-U. Hyperplasia of replicating PNS precursors. These micrographs show staged embryos of $61 / 2$ (left panels), $71 / 2$ (middle panels) and $81 / 2 \mathrm{~h} \mathrm{(right} \mathrm{panels)} \mathrm{of} \mathrm{development} \mathrm{(at} 25^{\circ} \mathrm{C}$ ) corresponding to middle stage 11, late stage 11 and stage 12, respectively (Campos-Ortega and Hartenstein 1985). All embryos had been incubated with BrdU for 30 min before fixation and anti-BrdU antibody staining. Anterior is to the left and dorsal is up. A-C Show replication patterns of wild-type embryos. Replication patterns of homozygous embryos with neurogenic mutations: D-F $N^{55 e 11}, \mathbf{G}-\mathbf{I}$ $m^{23}{ }^{23}, \mathbf{J}-\mathbf{L} D l^{9 \mathrm{P} 39}, \mathbf{M}-\mathbf{O} D l^{6 B 37}\left(25^{\circ} \mathrm{C}\right), \mathbf{P}-\mathbf{R} n e u^{K X 9}, \mathbf{S}-\mathbf{U} a m x^{1}$ embryos. $N$ and mam show moderately strong hyperplasia at 6 $1 / 2$ and $71 / 2 \mathrm{~h}(\mathbf{D}, \mathbf{E}, \mathbf{G}, \mathbf{H})$. The strong neurogenic mutations $D l^{9 \mathrm{P} 39}$ and $n e u^{\mathrm{KX} 9}$ also show strong hyperplasia of replicating PNS cells, and $D l^{6 B 37}$ and $a m x^{1}$ show moderate PNS hyperplasia. At $81 / 2 \mathrm{~h}$, wild-type $(\mathbf{C})$ as well as $D I(\mathbf{L}, \mathbf{O})$, neu $(\mathbf{R})$, amx $(\mathbf{U})$, $b i b$ (not shown) and $E(s p l)-C$ (not shown) embryos show almost no replicating cells in the PNS anymore - regardless of the allele strength (compare $\mathbf{L}$ and $\mathbf{O}$ ). However, $N$ and mam mutants still showed a marked excess of replicating cells in the peripheral ectoderm at $81 / 2 \mathrm{~h}(\mathbf{F}, \mathbf{I})$. Mutations that were also tested but are 
sistent with the idea that the supernumerary precursors go through the normal number of cell divisions.

The neurogenic mutants, $N$ and mam, resemble mutants of the other five neurogenic genes in the sensory precursor hyperplasia at the early stages of neurogenesis (6 $1 / 2$ and $71 / 2$ h, Fig. 1D, E, G, H). However, at later times, $81 / 2$ to $10 \mathrm{~h}$ of development, their phenotype is significantly different: Whereas replication of PNS cells has ceased in wild-type and five of the neurogenic mutants at that time (Fig. 1 C, L, O, R, U and 2A, B) many cells of the peripheral ectoderm are still replicating in $N$ and mam mutant embryos (Fig. $1 \mathrm{~F}, \mathrm{I}$ and $2 \mathrm{D}$, E). It is only after $10 \mathrm{~h}$ when no more replicating cells can be observed in $N$ and mam mutant embryos (Fig. 2F). Qualitatively the same result was obtained when $N$ and mam alleles of different strength were examined (see below and data not shown).

Since $N$ has a large maternal contribution (Jimenez and Campos-Ortega, 1982), we wondered whether maternal contribution may account for the prolonged replication seen in $N$ mutants. Germline clones of $N$ have been generated (see Materials and methods) in order to eliminate any wild-type $N$ gene product from the heterozygous mother. A more severe cuticle phenotype was present in embryos that were maternally and zygotically mutant for $N$ (data not shown, see Jimenez and CamposOrtega 1982). Embryos without maternal $N$ contribution were also more severely hypertrophic for replicating peripheral cells at $61 / 2$ and $71 / 2 \mathrm{~h}$. Similar to purely zygotic $N$ mutant embryos, embryos lacking both maternally and zygotically contributed $N$ function also showed many BrdU labeled PNS cells at 9 and $10 \mathrm{~h}$ (Fig. 2G, H). Therefore, it seems that the normal products of $N$ and mam are not only required during the time when sensory precursors normally emerge but also at later times, up to $2 \mathrm{~h}$ after the time when neurogenesis in the PNS normally takes place.

\section{$N$ and mam mutations probably cause the production of extra precursor cells beyond the normal time window for neurogenesis in the PNS}

The presence of BrdU labeled cells after $81 / 2 \mathrm{~h}$ of development in the peripheral ectoderm of $N$ and mam mu-

\footnotetext{
not shown: $\operatorname{Df}(8) N^{8}$ has a similar hyperplasia of replicating cells in the PNS as $N^{5011}, \operatorname{mam}^{223}$ is similar to $\operatorname{mam}^{23}, \operatorname{Df}(3 \mathrm{R}) E(\mathrm{spl})$ $R-A 7.1$ and $\operatorname{Df}(3 \mathrm{R}) E(s p l)^{8 D O 6}$ are similar to $n e u^{K X 9}$. bib $b^{I I 9-5}$ shows only a moderate hyperplasia of replicating cells in the PNS, less than that of $D l^{6 B 37}$ at $25^{\circ} \mathrm{C}$. Homozygous mutant embryos are easily recognized by the large excess of stained nuclei in the ventral neurogenic region which do not segregate from the ectodermal cell layer. (The ectoderm has terminated its last wave of replication at $6 \mathrm{~h}$; Bodmer et al. 1989). The dorsal ectoderm in an abdominal segment of all panels is bracketed. These regions contain the precursors for the lateral and the dorsal PNS clusters of sensory organs; the precursors for the ventral PNS clusters are obscured by replication in the CNS (Bodmer et al. 1989). In moderate to strong neurogenic mutants the ventral PNS precursors do not form (R. Bodmer, unpublished), presumably because most ectodermal cells in the ventral neurogenic region assume a neurogenic fate (see also Campos-Ortega 1988; Artavanis-Tsakonas and Simpson 1991)
}

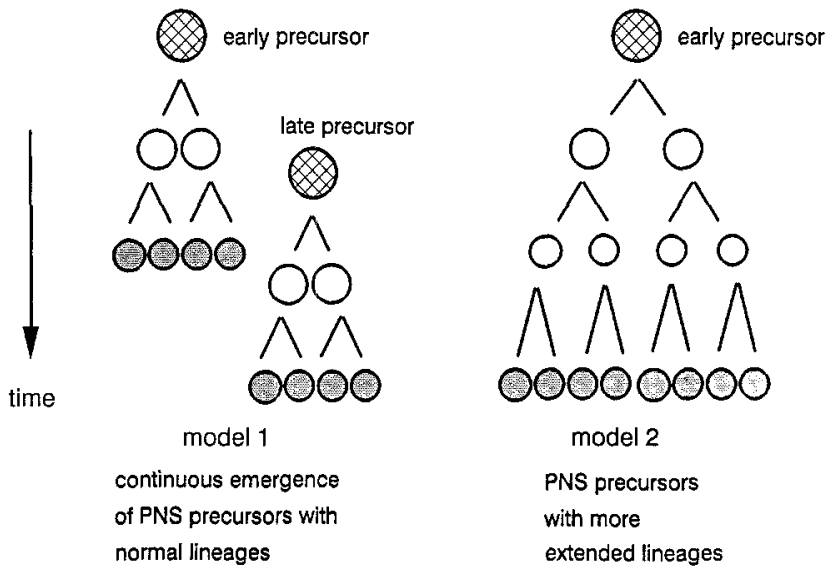

Fig. 3. Possible mechanisms for the late neurogenic phenotype of Notch and mastermind. The models are illustrated with the symmetrical division pattern of external sensory organ precursors (e.g. bristles, see Bodmer et al. 1989). In both models it is assumed that the cell cycle times do not change and that after the first division there is no prolonged $\mathrm{G}_{1}$ phase (see also Bodmer et al. 1989). Model 1 shows the hypothetical case where mutations in $N$ and mam causes additional precursor cells to emerge even after about $61 / 2 \mathrm{~h}$, the time PNS precursors in wild-type and the other neurogenic mutations have stopped incorporating BrdU. Alternatively, it is possible that the PNS precursor lineages in $N$ and mam are extended (model 2). Both models could explain why at 9 to $10 \mathrm{~h}$ of development $N$ and mam embryos still have many replicating PNS cells

tant embryos could be due to de novo recruitment of PNS precursors (Fig. 3A), due to additional rounds of cell division of preexisting precursors (Fig. 3B) or due to a lengthening of the cell cycle. In order to distinguish between the first two possibilities (which suppose unaltered cell cycle time) we exposed appropriately staged embryos to colchicine prior to incubation with BrdU (see Material and methods). This procedure locks dividing cells in metaphase and thereby prevents further cell divisions or DNA synthesis. With this treatment it is possible to distinguish cells that have just divided prior to BrdU incubation from newly emerged precursors that can still incorporate $\mathrm{BrdU}$ (epidermal mitosis stops at about $6 \mathrm{~h}$ of development). Embryos of wild-type, $N$, $D l$ (Fig. 4 and 5) and mam (data not shown) were treated with colchicine for one hour, between six and seven hours of development. This prevented most of the cells in wild-type embryos to incorporate BrdU (Fig. 4A), since division of most PNS precursors precede or overlap with the duration of colchicine treatment (Bodmer et al. 1989). Similarly, colchicine treated $D l$ embryos show very few labelled cells (Fig. 4E). In $N$ mutant embryos, on the other hand, BrdU was incorporated into many cells beneath the peripheral epidermis in the presence of colchicine (Fig. 4C). Up to about half of the BrdU labelled cells in $N$ mutant embryos which were not treated with colchicine remained in colchicine-treated embryos and are likely to correspond to precursor cells that form at this late stage of development (Fig. 5). In both wild-type and mutants of these seven neurogenic genes, the CNS precursors start division before the PNS precursors and continue dividing for several hours after 

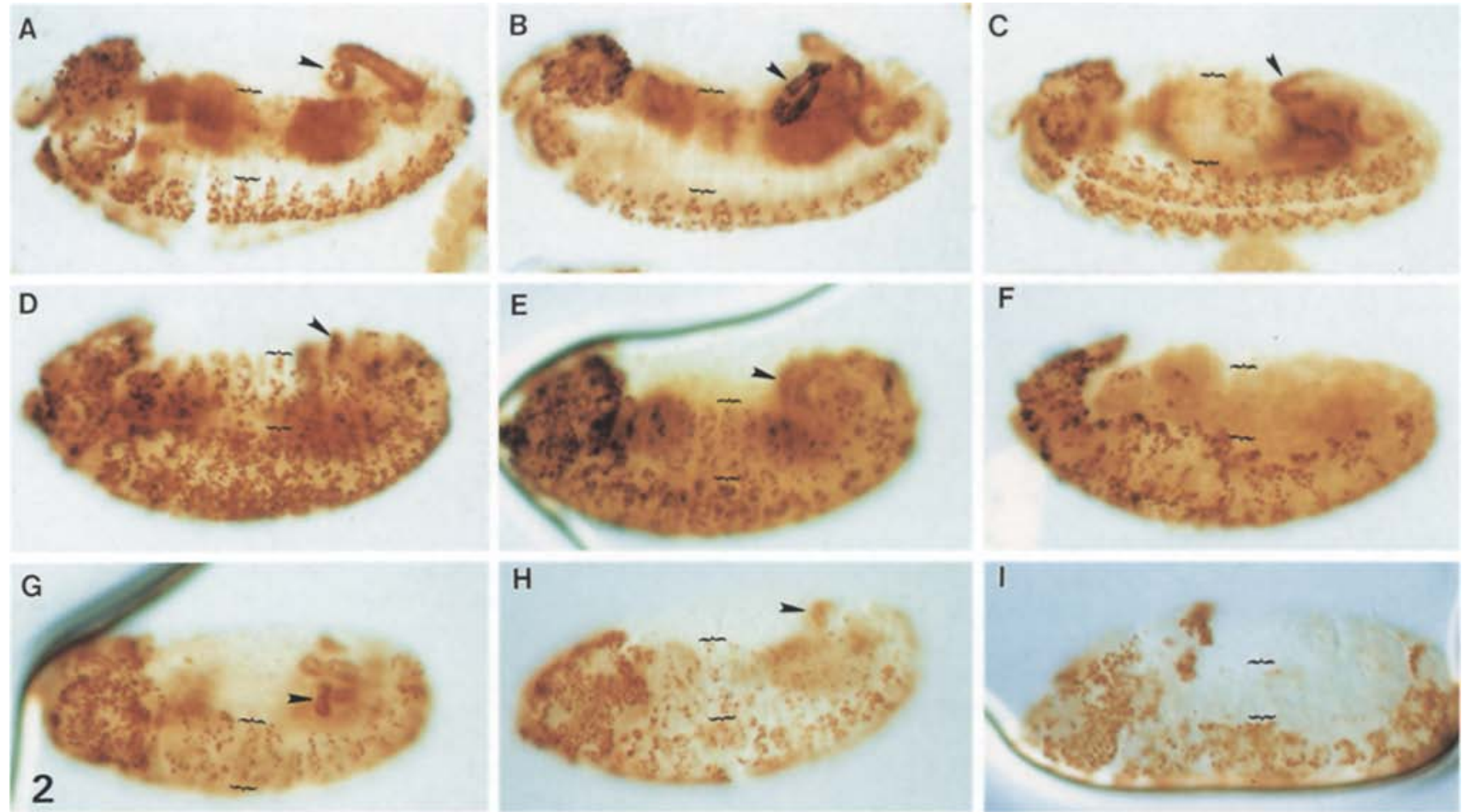

Fig. 2 A-I. Notch mutant embryos with and without maternal contribution. These micrographs show wild-type $(\mathrm{A}-\mathrm{C})$, zygotically mutant $N^{55 e 11}$ (D-F) and maternally and zygotically mutant $N^{5 \text { se11 }}(\mathbf{G}-\mathbf{I})$ embryos at $9 \mathrm{~h}$ (stage 12) (A, D, G), $10 \mathrm{~h}$ (stage 13) (B, E, H) and $11 \mathrm{~h}$ (stage 14) (C, F, I) of development. The maternal component was removed by mitotic recombination in $N^{55 e 11} /$ ovo $^{D 1}$ germline cells (see Materials and methods). Note that wild-type embryos show very few replicating cells in the PNS at 9 and $10 \mathrm{~h}$ of development, whereas zygotically as well as maternally and zygotically mutant $N$ embryos still have significant numbers of replicating cells in the periphery at these times. The developmental age of the embryos was independently confirmed by the following

criteria : $9 \mathrm{~h}$ embryos showed endoreplication in the hindgut, midgut, and the malpighian buds (arrowheads). In $10 \mathrm{~h}$ embryos, endoreplication is seen in the hindgut, midgut and malpighian buds which started to elongate. At $11 \mathrm{~h}$ the malpighian tubules were already quite elongated and most of the midgut had stopped endoreplication except for the central portion (see also Smith and OrrWeaver 1991). Even though neurogenic embryos appeared quite abnormal because of the neuronal hyperplasia, these characteristics did not seemed to be altered significantly. The approximate extent of the dorsal ectoderm of one segment is indicated by brackets in all panels

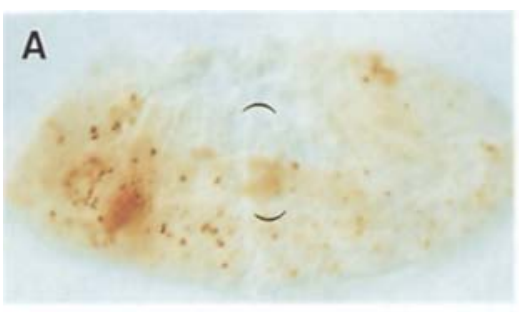

C
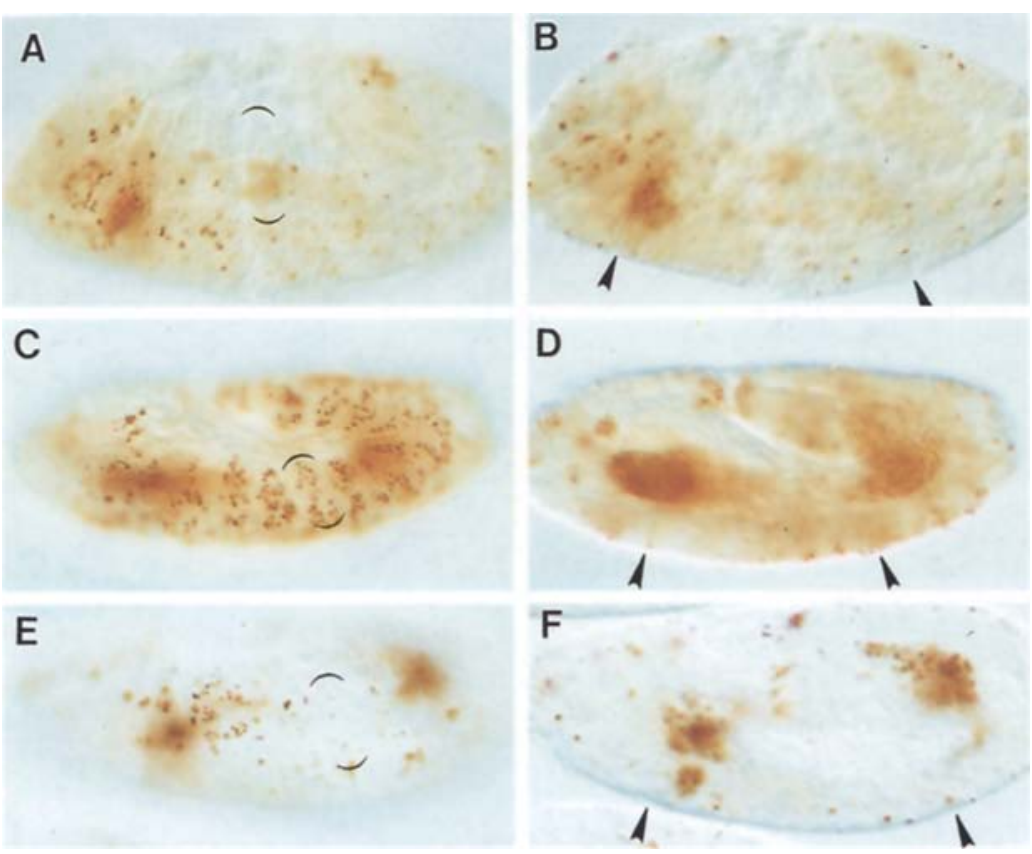

D

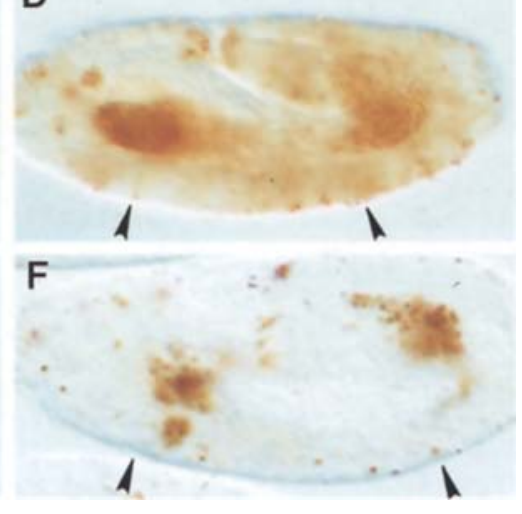

Fig. 4A-F. Colchicine effect on the number of late replicating cells in the PNS of neurogenic mutants These micrographs show $71 / 2$ to $8 \mathrm{~h}$ wild-type (A, B), $N^{55 e 11}(\mathbf{C}, \mathbf{D})$ and $D l^{6 B 37}(\mathbf{E}, \mathbf{F})$ embryos that have been treated with $0.2 \mathrm{mg} / \mathrm{ml}$ colchicine for one hour before BrdU incubation (see Materials and methods). Left and right panels are the same embryos in different focal planes. Peripheral focus depicts labelled cells in the PNS (A, C, E). Sagittal optical section shows CNS region indicated by arrowheads $(\mathbf{B}, \mathbf{D}, \mathbf{F})$. In $N^{55 e 11}$ embryos, many teplicating cells can be detected in the periphery (C) but not the CNS (D). Virtually no BrdU positive cells appear to be present in the PNS (and CNS) of wildtype $(\mathbf{A}, \mathbf{B})$ and $D l^{6 B 37}(\mathbf{E}, \mathbf{F})$ control embryos that received the same colchicine regime. Therefore, most replicating cells seen in untreated embryos at $71 / 2$ h (Fig. 1) are probably precursors that just completed a cell cycle before BrdU labelling and can be locked in metaphase with colchicine. Embryos that were sham-treated without colchicine could not be distinguished from untreated embryos. The number of BrdU positive cells is less in colchicinetreated compared to untreated $N^{55 e^{11}}$ embryos (see Fig. 5), presumably because the precursors that emerged early were blocked as in wild-type embryos. mam $^{23}$ embryos have a similar phenotype of late emerging precursors than $N$ embryos (data not shown) 
cessation of PNS precursor divisions. In the colchicinetreated wild-type, $N, D l$ and mam mutant embryos, BrdU incorporation into CNS precursors was blocked. Thus, these neurogenic mutations did not lengthen the duration of the cell cycle to much longer than one hour, so as to allow dividing CNS precursors to escape the block due to the one hour colchicine treatment. It seems unlikely that the $N$ and mam mutations should lengthen the cell cycle length of the PNS precursors but not the CNS precursors. The persistence of BrdU labelling of PNS precursors but not the CNS precursors in $N$ and mam mutants may be accounted for by the depletion of ectodermal cells available for the recruitment of CNS precursors.

\section{Acute elimination of neurogenic gene function causes immediate hyperplasia of replicating PNS precursors}

In order to test when the normal function of the neurogenic genes is required for controlling the number of PNS precursors, we have performed temperature shift experiments using two temperature-sensitive neurogenic mutations, $N^{\text {ts } 1}$ (Shellenbarger and Mohler 1978) and $D l^{6 B 37}$ (Lehmann et al. 1983). At $18^{\circ} \mathrm{C} N^{t s 1}$ is viable and the number of replicating cells is virtually wild-type (Fig. 6A-C, compare with Fig. $1 \mathrm{~A}-\mathrm{C}$ ). In contrast, if $N^{t s 1}$ embryos are maintained at $30-32^{\circ} \mathrm{C}$, the hyperplasia of PNS precursors is similar to that of strong $N$ mutations (such as $N^{55 e 11}$, data not shown). The $D l^{6 B 37}$ mutation is lethal, but shows only a mild hyperplasia of replicating peripheral precursors at $18^{\circ} \mathrm{C}$ (Fig. 6J-L). At $25^{\circ}$ (Fig. $1 \mathrm{M}, \mathrm{N}$ and Fig. 5) or at $30-32^{\circ} \mathrm{C}$ the number of replicating cells in the PNS of these $D l \mathrm{mu}-$ tant embryos is increased by two- and three-fold, respectively.

To test the effect of an acute elimination of neurogenic gene function on the number of replicating PNS cells, we maintained mutant embryos at $18^{\circ} \mathrm{C}$ until they reached a developmental age corresponding to that of $4-5,5-6$, or $6-7 \mathrm{~h}$ at $25^{\circ} \mathrm{C}$ (stage 9 to early stage 11 according to Campos-Ortega and Hartenstein 1985). The embryos were shifted to the non-permissive temperature of $30-32^{\circ} \mathrm{C}$ for one hour prior to BrdU exposure and subsequent fixation (see Materials and methods). $61 / 2$ and $71 / 2 \mathrm{~h}$ old $D l^{6 B 37}$ and $N^{t s 1}$ embryos that had received this heat-shock regime exhibited a drastic increase in BrdU labelled PNS precursors (Fig. 6D, E, $\mathrm{G}, \mathrm{H}$. The region of a dorsal abdominal PNS cluster is bracketed in Fig. 6 and 7). This acute hyperplasia of PNS precursors was similar to the phenotype of moderately strong $N$ (Fig. $1 \mathrm{D}, \mathrm{E}$ ) and $D l$ mutations, and was consistent with a previous report of increased sensory organ formation in $D l^{6 B 37}$ embryos subjected to a similar temperature shift (Hartenstein and Campos-Ortega 1986). This suggest that a more severe neurogenic phenotype can be induced with a 1-2 h time period throughout neurogenesis. Therefore, the normal replication pattern of PNS precursors requires the wild-type function of $N$ and $D l$ at the time of precursor recruitment $(5-7 \mathrm{~h}$ of development; Bodmer et al. 1989; Ghysen and O'K-

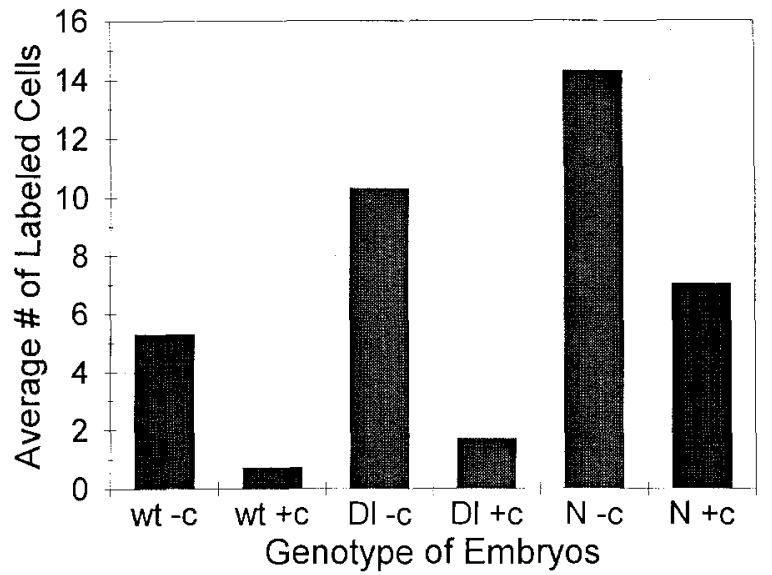

Fig. 5. Colchicine effect on BrdU incorporation in the PNS. Cell counts of the dorsal abdominal PNS cluster were carried out in $71 / 2 \mathrm{~h}$ embryos (see also Bodmer et al. 1989). The Y-axis is the average number of labelled cells in these clusters. On the $\mathrm{X}$-axis the genotype and colchicine treatment of the embryos is indicated. In wild-type (wt) embryos without colchicine $(-\mathrm{c})$ there are $5.3+/$ -0.9 S.D. labelled cells (25 abdominal clusters counted), with colchicine $(+\mathrm{c}) 0.7+/-0.7$ S.D. cells ( 23 clusters). In $D l^{6 B 37}$ embryos (DI) without colchicine there are $10.4+/-2.5$ S.D. labelled cells (40 clusters), with colchicine $1.7+/-0.9$ S.D. cells (39 clusters). In $N^{55 e 11}$ embryos $(\mathrm{N})$ without colchicine there are $14.3+/-2.3$ S.D. labelled cells ( 32 clusters), with colchicine $7.1+/-2.0$ S.D. (40 clusters)

ane 1989; Goriely et al. 1991). An earlier, partially wildtype function of these two genes is apparently not sufficient to appreciably attenuate the strength of the mutant phenotype in the PNS.

Elevating the temperature to the non-permissive level at later times (after $6-7 \mathrm{~h}$ of development at $25^{\circ} \mathrm{C}$ ) had a different effect in the $N^{t s 1}$ mutant embryos than in $D l^{6 B 37}$ mutants. Extra replicating cells still are still generated in the region of the PNS of $N$ mutant embryos (Fig. 6F) but not of $\mathrm{Dl}$ embryos (Fig. 6I). Similar to homozygous $N^{t s 1}$ mutants, $N^{t s 1} / N^{55 e 11}$ mutants were induced to produce extra BrdU labelled cells by incubation at $30-32^{\circ} \mathrm{C}$ for one hour after $6-7 \mathrm{~h}$ of development (data not shown). These additional replicating cells in the PNS region of $N$ embryos (Fig. 6F) are located just below the epidermis (as are wild-type PNS precursors), and they coincide with the position of the normal PNS clusters (see also Bodmer et al. 1989). Therefore, it is likely that these late replicating cells are, in fact, neuronal precursors.

In order to examine the identity of the cells in the PNS region that were acutely induced to replicate in $N$ and $D l$ mutants, we used anti-Cut antibodies as a marker of sensory organ cells. The Cut protein is known to be specifically expressed in a subset of sensory organ cells and their precursors (Blochlinger et al. 1990). $N^{t s 1}$ and $D l^{6 B 37}$ mutant embryos were shifted to the nonpermissive temperature for $11 / 4 \mathrm{~h}$ (same heat-shock regime as for BrdU labelling, Fig. 6) before fixation, and were subsequently stained with anti-Cut antibodies. When $N^{t s 1}$ and $D l^{6 B 37}$ mutant embryos were temperature-shifted at 4-5 and 5-6 h of development and fixed at $61 / 2$ and $71 / 2 \mathrm{~h}$ the number of Cut positive cells 

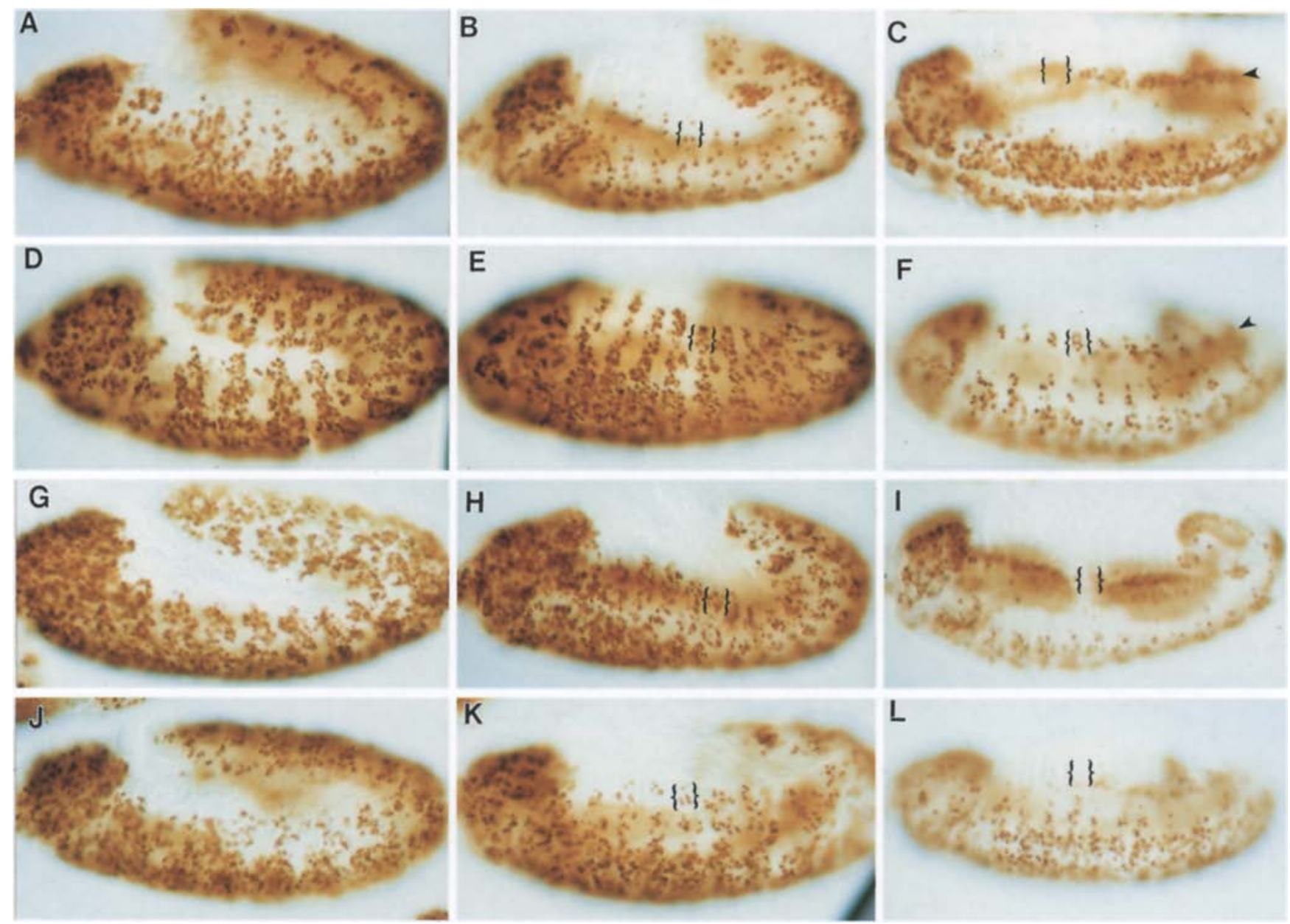

Fig. 6A-L. Acute inactivation of neurogenic gene function causes immediate hyperplasia of replicating PNS precursors. Ages of embryos are as in Fig. 1: Left panels are $61 / 2$, center $71 / 2$ and right $81 / 2 \mathrm{~h}$ old embryos. The region of a dorsal abdominal cluster is bracketed in the center and right panels. A-C are homozygous $N^{t s 1}$ embryos grown at $18^{\circ} \mathrm{c}$ (viable at this temperature). They are indistinguishable from wild-type (compare with Fig. $1 \mathrm{~A}-\mathrm{C}$. DF are $N^{t s 1}$ embryos that have been grown at $18^{\circ} \mathrm{C}$ and shifted to $32^{\circ} \mathrm{C}$ one hour prior to incubation with BrdU (see Material and methods). The extent of hyperplasia of replicating PNS precursors at $61 / 2$ (D) and $71 / 2(\mathbf{E}) \mathrm{h}$ is similar to what is seen in embryos mutant for a strong $N$ allele (Fig. $1 \mathrm{D}+\mathrm{E}$ ). A moderate hyperplasia is also seen at $81 / 2 \mathrm{~h}(\mathbf{F})$, but less severe than in Fig. 1 F. Arrowheads in (C and F) indicate reclications in the tracheal primordia. G-I are homozygous $D l^{6 B 37}$ embryos grown at $18^{\circ} \mathrm{C}$ and shifted to $32^{\circ} \mathrm{C}$ one hour prior to incubation with BrdU. The phenotype of replicating PNS cells in $(\mathbf{G}$ and $\mathbf{H})$ is more severe than with embryos continuously grown at $25^{\circ} \mathrm{C}$ (compare with Fig. $1 \mathrm{M}+\mathrm{N})$, or at $18^{\circ} \mathrm{C}(\mathbf{J}+\mathbf{K})$. Shifting the temperature to $32^{\circ} \mathrm{C}$ of 6-7 h old embryos ( $81 / 2 \mathrm{~h}$ old at the time of fixation) that are homozygous for $D l^{6 B 37}$ fails to induce replication in the PNS (I), similar to Fig. $1 \mathrm{~L}, \mathrm{O}, \mathrm{R} \& \mathrm{U})$. Note, however, that the same regime used with $N^{t s 1}$ embryos $(\mathbf{F})$ is still capable to acutely induce additional replicating PNS precursors was increased as expected (data not shown). When $N^{t s 1}$ and $D l^{6 B 37}$ mutant embryos were temperature-shifted at $6-7 \mathrm{~h}$ of development and fixed at $81 / 2 \mathrm{~h}$, no significant difference in the number of anti-Cut labelled cells were found between $D l^{6 B 37}$ embryos that were temperature-shifted and those that were not (data not shown). By contrast, heat-shocked $N^{t s 1}$ mutants at this time are still capable of producing additional, Cut-expressing cells in the PNS (Fig. 7, a dorsal abdominal cluster is bracketed). The heatshocked $N^{t s 1}$ mutant embryos ( 8 $1 / 2 \mathrm{~h}$ of age) have on average 23 Cut-expressing cells in the dorsal abdominal cluster as compared to 16 such cells in $N^{t s 1}$ mutant embryos without heat-shock (e.g. the one bracketed in Fig. 7). The additional PNS cells (ca. 7 in the dorsal abdominal cluster) in transiently temperature-shifted $N^{t s 1}$ mutants correspond, most likely, to the extra replicating cells seen with BrdU staining of similarly treated embryos (4-11 cells in the dorsal abdominal cluster, bracketed in Fig. $6 \mathrm{~F}$ ). This result suggests that the late replicating cells in $N$ mutant embryos are supernumerary PNS precursors rather than epidermal cells that have escaped mitotic arrest.

We conclude from these results that the wild-type $N$ gene product appears to be required until relatively late stages of neurogenesis (7-9 h of development) in order to prevent the recruitment of extra PNS precursors. By contrast, heat-shock inactivation of $D l$ during this time did not result in a late hyperplasia of PNS precursors.

In summary, these studies reveal that there are two classes of neurogenic genes which differ in their temporal requirement during PNS neurogenesis: All seven neurogenic genes are required initially to ensure the correct number of PNS precursors. Later, one class ( $N$ and mam) continues to be required in the peripheral ecto- 

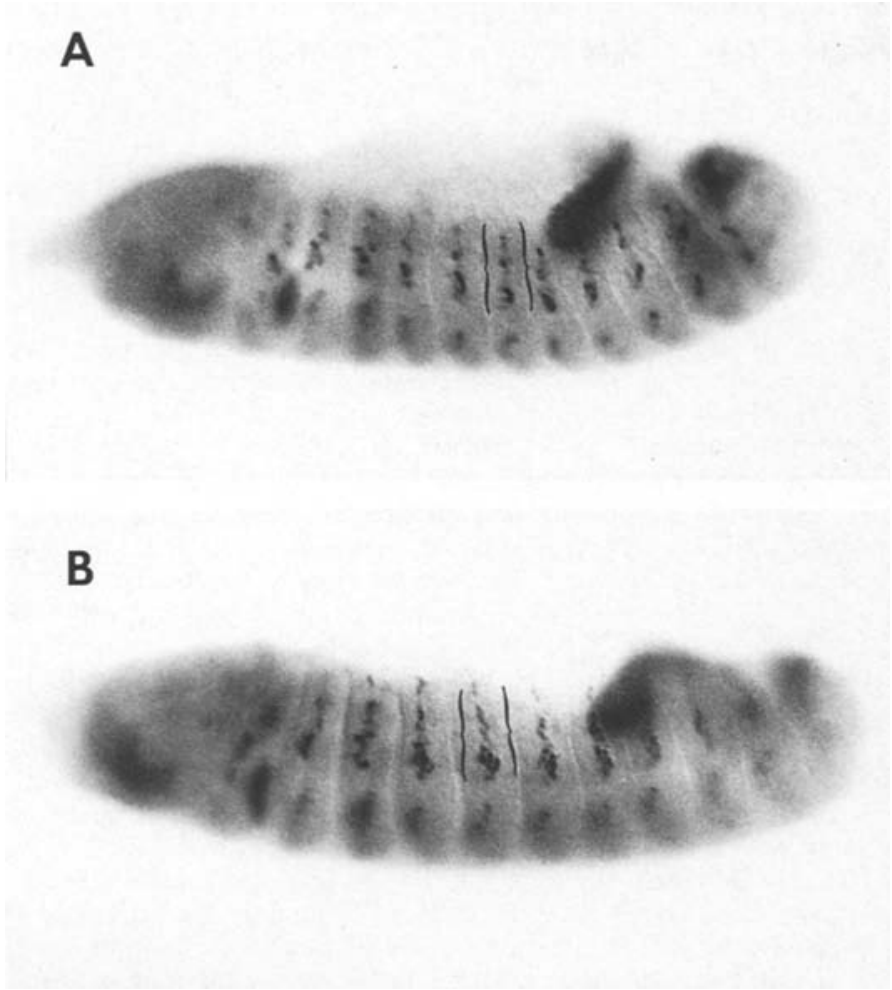

Fig. 7 A, B. Acute elimination of $N$ function in $N^{t s 1}$ mutant embryos causes hyperplasia of PNS precursors which express Cut, a nuclear protein specifically localized in a subset of sensory organ precursors. Virtually all cells in the dorsal PNS cluster of the abdominal segments express the Cut protein (a dorsal abdominal PNS cluster is bracketed). The average number of cut-expressing cells in this cluster is $16.1+/-1.2(n=26)$ in a wild-type embryo at $81 / 2 \mathrm{~h}$ of development. In a homozygous $N^{\text {ts } 1}$ mutant embryo grown at $18^{\circ} \mathrm{C} \mathrm{(A)}$, the average number is $16.4+/-1.7(n=28)$. In a homozygous $N^{t s i}$ embryo that was shifted from $18^{\circ}$ to $30-32^{\circ} \mathrm{C}$ for $11 / 4 \mathrm{~h}$ prior to fixation $(\mathbf{B}), 23.2+/-2.5(n=27)$ cells in the abdominal cluster express Cut. The regime for temperature-shift used here is the same as the one which led to hyperplasia of replicating cells that incorporate BrdU (Fig. 6F). Thus these extra replicating cells most likely correspond to PNS precursors that express Cut

derm, possibly for maintenance of the commitment to an epidermal fate. The other class ( $D l$, neu, bib, amx and $E(s p l))$ apparently is not required for this late epidermal maintenance function.

\section{Discussion}

Even though all the neurogenic genes exhibit a similar hyperplasia of neurons and neuronal precursors (Lehmann et al. 1981, 1983; Hartenstein and Campos-Ortega 1986; Campos-Ortega 1988), we found that they fall into two classes according to the time period during which the normal products of these genes are required, $D l$, $n e u, b i b$, amx and $E(s p l)-C$ belong to one class which appears to be required during the time when PNS precursors normally segregate (Fig. 1). By contrast, $N$ and mam are required not only during normal precursor segregation, but also for a more extended period of time after the completion of normal segregation of neuronal precursors (Figs. 1, 2, 6, 7). The experiments with tem- perature-sensitive alleles of $N$ and $D l$ suggest that the functions of these neurogenic genes are required throughout the period of neuronal precursor formation. The experiments with colchicine suggest that the $N$ and mam gene functions are required to suppress late recruitments of PNS precursors (Fig. 4 and 5): Replication in the PNS can be blocked by colchicine treatment between 6-7 h in $D l$ mutant embryos (Fig. 4E) but replication Since cell cycle times in the CNS of $N$ mutant embryos do not appear to be prolonged (Fig. $4 \mathrm{C}$ ), we favor the hypothesis that in mutant embryos of the $N / m a m$ class replicating cells emerge de novo after $7 \mathrm{~h}$ (until about $8 \mathrm{~h}$ of development), a phenomenon not observed in wild-type and in the other neurogenic mutants analyzed. The identity of the late replicating cells has been confirmed with an independent marker for sensory organ cells (Fig. 7). In a recent report, $N^{t s 1}$ was used to investigate microchaetae development in the adult fly. It has been suggested that $N^{+}$is required to limit the number of precursor recruitment until the divisions of sensory mother cells (Hartenstein and Posakony 1990). This result is consistent with our findings since $N$ mutant embryos show replicating cells in the PNS in the presence of colchicine after $7 \mathrm{~h}$ of development, a time when probably all precursors started their divisions. Therefore, we suggest that additional epidermal cells are recruited as PNS precursors late in neurogenesis in $N$ or mam mutants, and that the epidermal versus neural cell fate is not fixed, at that time, unless the wild-type $N$ and mam function is present.

\section{$N$ and mam may have a function \\ in maintaining ectodermal cell fates \\ after segregation of PNS precursors}

All the neurogenic genes apparently are required for segregation of the correct number of PNS precursors (Fig. 1; see also Goriely et al. 1991). In addition, we find that, unlike other neurogenic genes, $N$ and mam are also required to prevent additional cells in the peripheral epidermis from segregating and dividing even after all the normal PNS precursors have started dividing. The presence of the $N$ and mam proteins in these tissues (Kidd et al. 1989; Johanson et al. 1989; Bettler et al. 1991) is consistent with an additional function of these genes in the later process of restricting the number of neuronal precursor cells. It is interesting that $\mathrm{Dl}$, which has been implicated as the ligand for the Notch protein (Fehon et al. 1990; Heitzler and Simpson 1991), does not appear to be required at this later stage as does $N$. It is possible that the appropriate number of segregated neuronal precursors is maintained by a general cell adhesion function of $N$ (Hoppe and Greenspan 1986). This process may be regulated by mam which encodes a nuclear protein (Smoller et al. 1990) and is genetically epistatic to $N$ (de la Concha et al. 1988). It will be interesting to find out if $N$ expression is reduced in the ectoderm of mam mutants after $7 \mathrm{~h}$ of development.

In grasshopper, the ablation of a newly segregated CNS neuroblast results in recruitment of a neighboring 
epidermal cell to take its place (Doe and Goodman 1985), indicating that epidermal cells may retain the competence to become neural precursors for quite some time. In Drosophila, ectodermal cells when transplanted individually from an older to a younger embryo remain capable in choosing between an epidermal versus a neural fate for some time, even when transplanted from embryos that have terminated neuroblast segregation (Technau et al. 1988). The results reported in this paper show not only that the neurogenic genes control the number of neuronal precursors over the normal period of neuronal precursor formation, but a subset of these genes ( $N$ and $\mathrm{mam}$ ) are also needed to maintain the correct number of neuronal precursors.

Acknowledgements. This work is supported by NIH grant R01 NS29119-01A2 (awarded to R.B.) and by the Howard Hughes Medical Institute. L.Y.J and Y.N.J. are Howard Hughes Investigators.

\section{References}

Artavanis-Tsakonas S, Simpson P (1991) Choosing a cell fate: a view from the Notch locus. Trends Genet 7:403-408

Bettler D, Schmid A, Yedvobnick B (1991) Early ventral expression of the Drosophila neurogenic locus mastermind. Dev Biol 44:436-439

Blochlinger K, Bodmer R, Jan LY, Jan YN (1990) Patterns of expression of Cut, a protein required for external sensory organ development, in wild-type and cut mutant Drosophila embryos. Genes Dev 4:1322-1331

Bodmer R, Jan YN (1987) Morphological differentiation of the embryonic peripheral neurons in Drosophila. Roux's Arch Dev Biol 196:69-77

Bodmer R, Barbel S, Sheperd S, Jack J, Jan LY, Jan YN (1987) Transformation of sensory organs by mutations of the cut locus of D. melanogaster. Cell $51: 293-307$

Bodmer R, Carretto R, Jan YN (1989) Neurogenesis of the peripheral nervous system in Drosophila embryos: DNA replication patterns and cell lineages. Neuron $3: 21-32$

Boulianne GL, de la Concha A, Campos-Ortega JA, Jan LY, Jan YN (1991) The Drosophila neurogenic gene neuralized encodes a novel protein and is expressed in precursors of larval and adult neurons. EMBO J 10:2975-2983

Brand M, Campos-Ortega JA (1988) Two groups of interrelated genes regulate early neurogenesis in Drosophila melanogaster. Roux's Arch Dev Biol 197:457-470

Cagan RL, Ready DF (1989) Notch is required for successive cell decisions in the developing Drosophila retina. Genes Dev 3:1099-1112

Campos-Ortega JA (1988) Cellular interactions during early neurogenesis of Drosophila melanogaster. Trends Neurosci 11:400 405

Campos-Ortega JA, Hartenstein V (1985) The embryonic development of Drosophila melanogaster. Springer, Berlin Heidelberg New York

Campos-Ortega JA, Jan YN (1991) Genetic and molecular basis of neurogenesis in Drosophila melanogaster. Ann Rev Neurosci $14: 399-420$

Cabrera CV (1990) Lateral inhibition and cell fate during neurogenesis in Drosophila: the interactions between scute, Notch and Delta. Development 109:733-742

Caudy M, Grell EL, Dambly-Chaudiere C, Ghysen A, Jan LY, Jan YN (1988) The maternal sex determination gene daughterless has zygotic activity necessary for the formation of peripheral neurons in Drosophila. Genes Dev 2:843-852
Corbin V, Michaelson AM, Abmayr SM, Neel V, Alcamo E, Maniatis T, Young MW (1991) A role for the Drosophila neurogenic genes in mesoderm differentiation. Cell 67:311-323

Cubas P, de Celis JF, Campuzano S, Modelell J (1991) Proneural clusters of the achaete-scute expression and the generation of sensory organs in the Drosophila imaginal wing disc. Genes Dev 5:996-1008

Dambly-Chaudiere C, Ghysen A (1986) The sense organs in the Drosophila larva and their relation to the embryonic pattern of sensory neurons. Roux's Arch Dev Biol 195:222-228

Dambly-Chaudiere C, Ghysen A (1987) Independent subpatterns of sense organs require independent genes of the achaete-scute complex in Drosophila larvae. Genes Dev 1:297-306

Dambly-Chaudiere C, Ghysen A, Jan LY, Jan YN (1988) The determination of sense organs in Drosophila: interaction of scute with daughterless. Roux's Arch Dev Biol 197:419-423

de Celis JF, Mari-Beffa M, Garcia-Bellido A (1991) Cell autonomous role of the Notch gene, an epidermal growth factor homo$\log$, in sensory organ differentiation in Drosophila. PNAS $88: 632636$

de la Concha A, Dietrich U, Weigel D, Campos-Ortega JA (1988) Functional interactions of neurogenic genes of Drosophila melanogaster. Genetics 118:499-508

Doe CQ, Goodman CS (1985) Early events in insect neurogenesis. II. The role of cell interactions and cell lineage in the determination of neuronal precursor cells. Dev Biol 111:206-219

Fehon RG, Kooh JP, Rebay I, Regan CC, Xu T, Muskavitch MAT, Artavenis-Tsakonas S (1990) Molecular interactions between the protein products of the neurogenic loci Notch and Delta, two EGF-homologous genes in Drosophila. Cell 6:523534

Foe VE (1989) Mitotic pattern reflects cell commitment in the Drosophila embryo. Development 107:1-22

Ghysen A, Dambly-Chaudiere C (1989) The genesis of Drosophila peripheral nervous system: A sequential process. Trends Genet $5: 251-255$

Ghysen A, O'Kane C (1989) Neural enhancer-like elements as specific cell markers in Drosophila. Developement 105:35-52

Ghysen A, Dambly-Chaudiere C, Aceves E, Jan LY, Jan YN (1986) Sensory neurons and peripheral pathways in Drosophila embryos. Roux's Arch Dev Biol 195:281-289

Goriely A, Dumont N, Dambly-Chaudiere C, Ghysen A (1991) The determination of sense organs in Drosophila: effect of the neurogenic mutations in the embryo. Development 113:13951404

Haenlin M, Kramatschek B, Campos-Ortega J (1990) The pattern of transcription of the neurogenic gene Delta of Drosophila melanogaster. Developement 110:905-914

Hartenstein V, Campos-Ortega JA (1986) The peripheral nervous system of mutants of early neurogenesis in Drosophila melanogaster. Roux's Arch Dev Biol 195:210-221

Hartenstein V (1988) Development of Drosophila larval sensory organs: spatiotemporal pattern of sensory neurones, peripheral axonal pathways and sensilla differentiation. Developement 102:869-886

Hartenstein V, Posakony JW (1990) A dual function of the Notch gene in Drosophila sensillum development. Dev Biol 142:13-30

Heitzler P, Simpson P (1991) The choice of cell fate in the epidermis of Drosophila. Cell 64:1083-1092

Hoppe PE, Greenspan RJ (1986) Local function of the Notch gene for embryonic ectodermal choice in Drosophila. Cell 46:773783

Hoppe PE, Greenspan RJ (1990) The Notch locus of Drosophila is required in epidermal cells for epidermal development. Developement 109:875-885

Jan YN, Jan LY (1990) Genes required for specifying cell fates in Drosophila embryonic sensory nervous system. Trends Neurosei 13:493-498

Jimenez F, Campos-Ortega J (1982) Maternal effects of zygotic mutants affecting early neurogenesis in Drosophila. Roux's Arch Dev Biol 191:191-201 
Jimenez F, Campos-Ortega J (1990) Defective nẹroblast commitment in mutants of the achaete-scute complex and adjacent genes of $D$. melanogaster. Neuron 5:81-89

Johanson KM, Fehon RG, Artavanis-Tsakonas S (1989) The Notch gene product is a glycoprotein expressed on the cell surface of both epidermal and neuronal precursor cells during Drosophila development. J Cell Biol 109:2427-2440

Juergens G, Wieschaus E, Nuesslein-Volhard C (1984) Mutations affecting the pattern of larval cuticle in Drosophila melanogaster. II. Zygotic loci on the third chromosome. Roux's Arch Dev Biol 193:283-295

Kidd S, Baylies MK, Gasic GP, Young MW (1989) Structure and distribution of the Notch protein in developing Drosophila. Genes Dev 3:1113-1129

Klaempt C, Knust E, Tietze K, Campos-Ortega J (1989) Closely related transcripts encoded by the neurogenic gene complex Enhancer of split of Drosophila melanogaster. EMBO J 8:203211

Knust E, Tietze K, Campos-Ortega J (1987) Molecular analysis of the neurogenic locus Enhancer of split of Drosophila melanogaster. EMBO J 6:4113-4123

Kopczynski CC, Muskavitch MAT (1989) Complex spatio-temporal accumulation of alternative transcripts from the neurogenic gene Delta during Drosophila embryogenesis. Developement 107:623-636

Kopczynski CC, Alton AK, Fechtel K, Kooh PJ, Muskavitch MAT (1988) Delta, a Drosophila neurogenic gene is transcriptionally complex and encodes a protein related to blood coagulation factors and epidermal growth factor of vertebrates. Genes Dev $2: 1723-1735$

Lehmann R, Dietrich W, Jimenez J, Campos-Ortega J (1981) Mutations of early neurogenesis in Drosophila. Roux's Arch Dev Biol 190:226-229

Lehmann R, Jimenez F, Dietrich W, Campos-Ortega J (1983) On the phenotype and development of mutants of early neurogenesis in Drosophila melanogaster. Roux's Arch Dev Biol 192:6274

Lindsley DL, Grell EH (1968) Genetic variations of Drosophila melanogaster. Carnegie Institute Publ Washington

Lindsley DL, Zimm G (1985) The Genome of Drosophila melanogaster. Part 1. Dros Inf Serv 62

Lindsley DL, Zimm G (1990) The Genome of Drosophila melanogaster. Part 4. Dros Inf Serv 68

Martin-Bermudo MD, Martinez C, Rodriguez A, Jimenez F (1991) Distribution and function of the lethal of scute gene product during early neurogenesis in Drosophila. Development $113: 445-454$

Rao Y, Jan LY, Jan YN (1990) Similarity of the product of the Drosophila neurogenic gene big brain to transmembrane channel proteins. Nature 345:163-167
Rao Y, Bodmer R, Jan LY, Jan YN (1992) The big brain gene in Drosophila functions to control the number of neuronal precursors. Developement 116:31-40

Ruohola H, Bremer KA, Baker D, Swedlow SR, Jan LY, Jan YN (1991) Role of neurogenic genes in establishment of follicle cell fate oocyte polarity during oogenesis in Drosophila. Cell 66:433-449

Romani S, Campuzano S, Macagno ER, Modolell J (1989) Expression of achaete and scute genes in Drosophila imaginal discs and their function in sensory organ development. Genes Dev 3:997-1007

Schrons H, Knust E, Campos-Ortega J (1992) The Enhancer of split complex and adjacent genes in the $96 \mathrm{~F}$ region in Drosophila melanogaster are required for segregation of neural and epidermal progenitor cells. Genetics $132: 481-503$

Shellenbarger DL, Mohler JD (1978) Temperature-sensitive periods and autonomy of pleiotropic effects of $I(1) N^{t s 1}$, a conditional Notch lethal in Drosophila. Dev Biol 62:432-446

Skeath JB, Carroll SB (1991) Regulation of achaete-scute expression and sensory organ pattern formation in the Drosophila wing. Genes Dev 5:984-995

Skeath JB, Carroll SB (1992) Regulation of proneural gene expression and cell fate during neuroblast segregation in the Drosophila embryo. Development 114:939-946

Smith AV, Orr-Weaver TL (1991) The regulation of the cell cycle during Drosophila embryology: the transition to polyteny. Developement 112:997-1008

Smoller D, Friedel C, Schmid A, Bettler D, Lam L, Yedvobnick B (1990) The Drosophila neurogenic locus mastermind encodes a nuclear protein unusually rich in amino acid homomers. Genes Dev 4:1688-1700

Technau GM, Becker T, Campos-Ortega J (1988) Reversible commitment of neural and epidermal progenitor cells during embryogenesis of Drosophila melanogaster. Roux Arch Dev Biol 197:413-418

Vaessin H, Vielmetter J, Campos-Ortega J (1985) Genetic interactions in early neurogenesis of Drosophila melanogaster. J Neurogenet 2:291-308

Vaessin H, Campos-Ortega J (1987) Genetic analysis of Delta, a neurogenic gene of Drosophila melanogaster. Genetics 116:433445

Wharton KA, Johanson KM, Xu T, Artavanis-Tsakonas S (1985) Nucleotide sequence from the neurogenic locus Notch implies a gene product that shares homology with proteins containing EGF-like repeats. Cell 43:567-581

Ziemer A, Tietze K, Knust E, Campos-Ortega J (1988) Genetic analysis of Enhancer of split, a locus involved in neurogensis in Drosophila melanogaster. Genetics 119:63-74 